\title{
Kwaliteit voor minder geld
}

Op 21 januari demonstreerden zo'n 1000 hoogleraren en vele duizenden studenten tegen de bezuinigingsplannen van de regering. Of dat iets heeft opgeleverd, is zeer de vraag. Het wetsontwerp dat de staatssecretaris van OCW begin februari naar de Tweede Kamer heeft gestuurd is weliswaar iets veranderd ten opzichte van zijn eerdere plannen, maar de boodschap blijft precies hetzelfde: universiteiten zullen de komende tijd drastisch moeten bezuinigen op hun onderwijs en onderzoek. Tegelijkertijd zijn er via het ministerie van VWS ongekende bezuinigingen in de zorg aangekondigd die van invloed zullen zijn op de werkdruk voor medisch specialisten en daardoor effect zullen hebben op medisch specialistische vervolgopleidingen. En dat terwijl per 1 januari jl. het nieuwe Kaderbesluit voor de vervolgopleidingen in werking is getreden waarbij de eisen die aan opleiders en artsen in opleiding tot specialist (aios) worden gesteld flink toenemen. In deze omstandigheden verwacht het kabinet ook nog eens dat Nederland een prominente positie blijft behouden (dan wel krijgt) op de rankingslijstjes op het gebied van onderwijs en innovatie. Kortom, een ware uitdaging!

De belangrijke vraag is nu hoe we de kwaliteit van ons onderwijs en de opleidingen kunnen handhaven terwijl er op de financiële middelen die daarvoor tot nu toe beschikbaar waren, zoveel gekort gaat worden. We zullen daar een antwoord op moeten vinden. Wellicht hopen sommigen dat de Eerste Kamer de kabinetsplannen blokkeert of het kabinet dwingt tot aanpassingen. Dit zal echter weinig verande- ren aan de realiteit dat we het de komende jaren met minder geld zullen moeten doen. We hebben met veel inzet en overtuiging gedemonstreerd. Het heeft niet opgeleverd wat we gehoopt hadden. $\mathrm{Nu}$ moeten we verder en de uitdaging aangaan.

Voor het TMO is er nog een andere uitdaging: de beslissing om van het TMO een Engelstalig tijdschrift te maken. Tijdens de ledenvergadering in november $\mathrm{jl}$. heeft Olle ten Cate als voorzitter van het NVMO bestuur daar een warm pleidooi voor gehouden. Het uitgangspunt daarbij is dat het Engelse TMO niet meer mag kosten dan het Nederlandse TMO. Op dit moment is de redactie bezig met een aanpassing van het businessplan om aan deze voorwaarde te kunnen voldoen. En we zijn daar optimistisch over! Dat betekent dat we ervan uitgaan dat het Redactioneel van de hoofdredacteur in het eerste nummer van Perspectives in Medical Education (voorlopige werktitel) in 2012 een nieuwe fase in het bestaan van het tijdschrift van de Nederlandse Vereniging van Medisch Onderwijs zal markeren.

Ik hoop dat dit eerste nummer van de nieuwe jaargang $\mathrm{u}$ weer veel leesplezier bezorgt. Het is zeer gevarieerd en past in die zin bij de brede doelgroep waarvoor de NVMO een platform wil zijn.

\section{Jan Borleffs}

